\title{
Gudommelig gymnastikk - kroppslighetens plass i Rudolf Steiners pedagogiske tenkning
}

\section{Dag Øystein Nome*}

Universitetet $i$ Agder

\section{Sammendrag}

Artikkelen drøfter Rudolf Steiners vektlegging av kroppslighetens betydning i skolen med bakgrunn i analyser av foredragsrekken Oppdragelsen og tidens åndsliv holdt i 1923 i Ilkley, England (Steiner, 1986). Beskrivelsene av kroppens betydning for barns danningsprosesser i foredragene blir her drøftet i lys av annen samtidig reformpedagogisk tenkning. Intensjonen er å se hvorvidt Steiners verdsetting av kropp og bevegelse i skolen kan være et relevant bidrag til dagens utdanningspolitiske debatt. Steiner betonte kroppslige prosesser som et fundament for mentale prosesser. Han mente skolen burde gi kropp og bevegelse en sentral plass blant skolens kunstneriske arbeidsformer og anse dem som viktige instrumenter for helhetlige danningsprosesser. Eurytmifaget står her sentralt. Steiners pedagogiske foredrag blir i artikkelen forstått som et eksempel på en tenkning om skole som strekker seg ut over et snevert læringsfokus.

\section{Nøkkelord: Steinerpedagogikk; kroppslighet; danning; utdanningskritikk}

\begin{abstract}
Divine Gymnastics - The Significance of the Body in Rudolf Steiner's Pedagogy This article discusses how Rudolf Steiner's belief in the importance of the body and movement in school comes across in his book Oppdragelse og tidens åndliv (1986) a collection of public lectures held in 1923 in Ilkley, England. I will juxtapose Steiner's descriptions of the body's significance for children's processes of bildung with other ideas of reform pedagogy. My intention is to see whether Steiner's appreciation of the body and movement in school can be of relevance to today's debate on educational policy. Steiner views bodily processes as a foundation for mental processes and argues that one should make movement a central part of schools' artistic work and view it as a contribution to the holistic processes of bildung. In the lectures, he places special emphasis on eurythmy as a school subject. The conclusion is that Steiner's lectures contribute to viewing education as something more than knowledge-acquisition.
\end{abstract}

Keywords: Waldorf education; embodiment; bildung; critique of education

Mottatt: Oktober, 2018; Antatt: April, 2019; Publisert: September, 2019

\footnotetext{
^Korrespondanse: Dag Nome, epost: dag.nome@uia.no

(C) 2019 Dag Øystein Nome. This is an Open Access article distributed under the terms of the Creative Commons Attribution 4.0 International License (https://creativecommons.org/licenses/by-nc/4.0/), allowing third parties to copy and redistribute the material in any medium or format and to remix, transform, and build upon the material for any purpose, even commercially, provided the original work is properly cited and states its license. 


\section{Innledning}

Steinerskolene er ifølge Anne Mette Stabel (2016) i ferd med å revurdere sitt forhold til idégrunnlaget, antroposofien. Én av de øvelsene dette krever, er å bestemme seg for hva de skal gjøre med arven etter Rudolf Steiner. Hva er fortsatt relevant i de pedagogiske foredragene hans? Jeg retter i denne artikkelen oppmerksomheten mot et hittil lite belyst aspekt ved Steiners pedagogiske tenkning, nemlig vektleggingen av kroppslighetens betydning for barns danningsprosesser i skolen.

Det er i liten grad gjort systematiske undersøkelser av dette aspektet ved Steiners pedagogiske tenkning tidligere, selv om noen av perspektivene kommer fram i en artikkel av Johannes Wagemann (2015). Wagemanns artikkel er fortrinnsvis knyttet til yngre barn. Kroppslighet i steinerpedagogikken er også drøftet i en mer populærvitenskapelig form av Arve Mathisen ved flere anledninger (2000a, 2000b).

Etter min mening er kroppens og bevegelsens plass i skolehverdagen ett av de mest iøynefallende kjennetegn ved steinerpedagogisk praksis. I den generelle delen $\mathrm{i}$ steinerskolens læreplan kan en blant annet lese følgende:

Fagene kommer til orde gjennom bevegelsesaktiviteter. En steinerpedagog bruker bevegelse til så og si alle undervisningsfag de første skoleårene. I matematikk læres gangetabellen rytmisk gjennom hopp og klapp, og i skriveopplæringen utledes bokstavformene av male- og tegneøvelser. Man søker overalt å skape en samvirkning mellom hånd og ånd (Steinerskoleforbundet, 2007, s. 20).

Læreplanens betoning av kropp og bevegelse har opphav i Steiners pedagogiske tenkning, og jeg undersøker i denne artikkelen Steiners paradoksale og mangesidige beskrivelser av kroppslighet i skolen med utgangspunkt i en foredragsrekke om pedagogikk av Steiner fra 1923. Den er kjent i bokform under tittelen Oppdragelse og tidens åndsliv (Steiner, 1986). For å plassere hans tenkning i et utdanningsfilosofisk landskap, sammenstiller jeg Steiners idékompleks med reformpedagogiske ideer fra hans egen samtid som berører kroppens betydning i skolen. John Deweys samtidige utdanningsfilosofiske refleksjoner om kroppens plass i skolen vil stå sentralt i denne artikkelen.

Jeg vil fortrinnsvis belyse danningsperspektivet ved å involvere hele mennesket i en undervisningskontekst. Med danningsperspektiv menes her undervisning som et middel til utvikling av menneskers individuelle og sosiale egenskaper, med mål om å utvikle autonome, men samtidig ansvarlige medborgere.

Avslutningsvis vil jeg knytte dette danningsperspektivet opp mot andre kritiske stemmer $\mathrm{i}$ vår tids skoledebatt. Kan noen av perspektivene Steiner uttrykte $\mathrm{i}$ foredragene holdt i 1923, bidra til moderne kritikk av overfokusering på læring og kvalifisering i dagens skole? Min intensjon er derfor, med utgangspunkt i Oppdragelse og tidens åndsliv, å peke på Steiners eventuelle utdanningsfilosofiske sprengkraft i vår tid, vel vitende om at én foredragsrekke bare gir et lite utsnitt av Steiners komplekse forestillingsverden. Først vil det derfor være nødvendig å tegne et bilde av den 
utdanningsmessige konteksten Steiner befant seg i på 1920-tallet, som han må leses inn i. Det dreier seg ikke minst om fremveksten av reformpedagogiske ideer og en medfølgende kritikk mot en dualistisk forståelse av mennesket.

\section{Reformpedagogikkenes oppgjør mot dualismen}

Reformpedagogikk er en ganske upresis betegnelse på ulike retninger som fra omkring 1900 på ulike måter ønsket å utfordre tradisjonell undervisning, den "gamle» skolen, puggeskolen eller bokskolen (Bø \& Helle, 2008). Det har vært vanlig å regne Steiner og Waldorfskolen med i den store og uensartede reformpedagogikk-familien (se Myhre, 1971) selv om Steiner neppe kan sies å være en typisk reformpedagog (Marstrander, 2015). Han fastholdt blant annet ideen om læreren som en naturlig autoritet og la også vekt på verdien av å lære ting utenat uten at det nødvendigvis er kognitivt forstått. ${ }^{1}$

Det er vanskelig å gi en kort sammenfatning av fellestrekk ved reformpedagogikk, men et sitat fra den norske skolereformatoren Anna Sethne peker på noen reformpedagogiske kjennetegn: «Barnets interesser er utgangspunkt for undervisningen, det skal selv medvirke og oppdage, ikke lære seg efter de voksnes system og deres erfaring. Det skal selv erfare i fri virksomhet» (Sethne, 1930, s. 110). Sethne var talsperson for arbeidsskolepedagogikken, og som det fremgår av sitater, var hensikten at kunnskap skulle ha sin opprinnelse i elevenes egen frie virksomhet. Med uttrykket frie virksomhet mente Sethne at barna skulle oppdage sin egen verden gjennom sanser, språk, følelsesliv og vilje (Sethne, 1930). At sanser og vilje ble knyttet til læringsprosessen, innebar uvilkårlig at reformpedagogene på ulike måter ga rom for kroppen og bevegelse.

Enhver reformpedagogisk refleksjon omkring kroppens plass i skolen vil måtte forholde seg kritisk til en dualistisk spalting av mennesket i kropp og sjel. Noe grovt kan en si at dualisme i vestlig moderne tenkning har sin rot i Descartes' filosofi om det rasjonelle jeg. Dualismen innebar at vårt rasjonelle jeg ble forstått som noe som står utenfor verden, og mennesket kunne derfor giøre naturen, andre mennesker og sin egen kropp til gjenstand for objektiv iakttakelse og tankemessig refleksjon (Fjelland, 2007).Vitenskapsteoretisk innebar dette et skarpt skille mellom empirisme og intellektualisme. Empirismen innebar at kroppen ble sett på som en objektiv iakttagbar mekanisk gjenstand bundet til de samme årsakslover som resten av den materielle verden. Intellektualismen innebar forestillingen om den rene tenkningen som subjektiv og med kroppens sanser som et panoramavindu mot verden konstruerer mening og struktur (Hangaard Rasmussen, 1996). At kroppen hadde noe som helst med bevisstheten, subjektiviteten eller tenkningen å gjøre, ble sett bort ifra, og det er påpekt at dette gradvis lot seg merke på flere samfunnsområder. I industrihallene ble kroppen en maskin blant andre maskiner, og i skolen skulle kroppens vitalitet

\footnotetext{
${ }^{1}$ Se blant annet ss. 25 og 30 i boka Barnets oppdragelse (Steiner, 1994).
} 
og bevegelsestrang legges igjen utenfor klasseromsdøren. Innenfor var det den rene tenkningen som var idealet (Levin, 1985).

Flere av forrige århundrets pedagogiske tenkere tok derfor et oppgjør med den dualistiske tenkemåten. Dette er ikke minst tydelig hos John Dewey. Han uttrykte seg slik da han i Democracy and Education (1916) skulle karakterisere dualismens konsekvenser for undervisning: "It would be impossible to state adequately the evil results which have flowed from this dualism of mind and body" (Dewey, s. 165). Ifølge Dewey ble kroppslig aktivitet ansett som en inntrenger som skulle holdes unna klasserommet til tross for at alle kognitive prosesser har opphav i kroppslige aktiviteter. Det har medført at begrepet elev er knyttet til helt bestemte forestillinger om forholdet mellom kropp og sinn:

The very word pupil has almost come to mean one who is engaged not in having fruitful experiences but in absorbing knowledge directly. Something which is called mind or consciousness is severed from the physical organs of activity (Dewey, 1916, s. 164).

Et læringsinnhold som tilegnes i en slik kontekst, vil aldri fullt ut gi mening for elevene fordi det er frikoblet kroppen, sansene og det følelsesmessige engasjementet som vekkes gjennom å være involvert i verden med hele seg. Dewey sa det slik: «[B]odily activity is divorced from the perception of meaning» (Dewey, 1916, s. 165). Han henviste til hvordan barn lærer før de begynner på skolen. Da oppstår læring av kroppslige aktiviteter i meningsfulle situasjoner. Sansene laster ikke ekstern kunnskap inn i hjernen, men sansene åpner for kunnskap fordi de brukes aktivt til å utføre noe med en hensikt og som setter spor i barnets omgivelser (Dewey, 1916, s. 167).

En helhetlig anti-dualistisk eller monistisk tenkning om læring, hvor kroppens betydning er vektlagt, var med andre ord et sentralt element i reformpedagogisk tenkning. Denne tenkemåten gjorde seg i høyeste grad også gjeldende hos Rudolf Steiner. Før jeg går nærmere inn på hvordan Steiner håndterte det dualistiske problemet, vil det være nødvendig med en presentasjon av mine kilder og en kort redegjørelse for mine metodiske valg.

\section{Utfordringer ved å lese Steiners foredrag}

Det er en utfordring å gjøre analyser av Rudolf Steiners pedagogiske idekompleks. Det skyldes først og fremst at han selv førte svært lite i pennen som kan anses som direkte metodiske eller didaktiske anvisninger. Med unntak av den lille boka Barnets oppdragelse fra åndsvitenskapens synspunkt (Steiner, 1994), som ble skrevet ti år før den første Waldorfskolen ${ }^{2}$ så dagens lys, er det for det meste bare referat fra de peda-

\footnotetext{
${ }^{2}$ Steiner omtalte selv skolene som Waldorfskoler og pedagogikken som waldorfpedagogikk etter navnet på den første skolen i Stuttgart. I gjennomgangen av foredragene er det derfor de betegnelsene jeg også bruker.
} 
gogiske foredragene en har å forholde seg til. Omkring oppstarten og spredningen av waldorfskoleinitiativet fra 1919 holdt han et stort antall slike foredrag som, basert på andres nedtegnelser, ble utgitt i bokform i løpet av hundre år. Å analysere tilhøreres referat av muntlige foredrag er krevende fordi en må ta høyde for at det allerede har skjedd en tolkning av fremstillingen idet de ble skrevet. Siden Steiner så over en del av referatene før de ble publisert, er det allikevel mulig å lese dem som tilnærmet den formen han selv ville ha skrevet dem dersom det var et bokmanus.

Den største utfordringen ved å analysere Steiners tekster og foredrag er hans uortodokse omgang med historiske eller naturvitenskaplige forhold. Han hadde en giennomgående tendens til å påberope seg innsikt som vanskelig kan etterprøves. Det er ikke problematisk at han hadde sine originale tolkninger av historiske, vitenskapelige eller sosiale fenomen. Det problematiske er at han hevdet at han ikke tolket, men gjenga kjensgjerninger ingen andre hadde hatt innsikt $\mathrm{i}$. I foredragene jeg har analysert, dukker det opp formuleringer som denne: «Historien forteller ikke lenger noe om disse ting, - i tidens løp er de blitt totalt glemt. Ikke desto mindre dreier det seg her om faktiske forhold» (Steiner, 1986, s. 28). Jeg skal ikke bruke mye tid på å drøfte hans vitenskapelige metode, men hans viktigste metodiske anliggende så ut til å være å avvise en mekanisk naturvitenskapelig tankemåte anvendt på menneskelige forhold. I studier av mennesket ville han erstatte intellektuell vitenskapelighet med «kunstnerisk innfølingsevne» (Steiner, 1986, s. 12). Flere har brukt metoder fra kunst eller estetikk som en måte å beskrive kvalitativ humanvitenskap på (som hos Eisner, 1991). Det er imidlertid problematisk når en slik kunstnerisk innfølingsevne blir anvendt som sannhetsvitne for historiske hendelser, slik Steiner hadde en tendens til. Med disse betenkelighetene i mente skal jeg kort presentere foredragsrekken jeg har brukt som kilde for drøftingen.

\section{Kort om kildene}

Steiner holdt tre foredragsrekker for lærere i England mellom 1922 og 1924, og de er alle utgitt $\mathrm{i}$ bokform på norsk. Jeg har valgt å analysere den andre foredragsrekken, da den er tydeligst i sin systematiske drøfting av kroppens betydning for undervisning. Foredragene ble holdt i Ilkley i august 1923 etter invitasjon fra lærere som hadde fattet interesse for Waldorfskolens praksis etter å ha hørt Steiner på en offentlig lærerkongress i Oxford året før. De hadde i mellomtiden besøkt moderskolen i Stuttgart hvor Steiner selv arbeidet som leder, og dette var lærerkretsen som siden etablerte de første Waldorfskolene på de britiske øyer (Paull, 2011). Steiner holdt denne gangen 14 foredrag, og de favner et bredt spekter av pedagogikkens idegrunnlag og praksis, slik det er naturlig når målgruppen er lærere som står på terskelen til å starte sine egne Waldorfskoler. Det var med andre ord et intensivt introduksjonskurs han holdt. Det medførte at foredragene på den ene siden kan oppleves som overfladiske siden de er preget av at han skulle favne svært mange ulike forhold omkring undervisning og derfor mangler tilstrekkelig dybde i sin argumentasjon. På den andre siden gir denne 
formen en god anledning til å få et inntrykk av hva han selv anså som det viktigste budskapet. Jeg har med andre ord lest foredragene som en samling av det han synes var aller viktigst at lærere visste om Waldorfskolens ide og praksis før de selv kunne praktisere.

Foredragene ble først utgitt i bokform i 1927, altså to år etter Steiners død. Det innebærer derfor at tittelen Oppdragelse og tidens åndsliv (Gegenwärtiges Geistesleben und Ertziehung) høyst sannsynlig ikke er hans egen. Tittelen er interessant fordi den kan leses som et uttrykk for Waldorfskolenes uttalte sosiale misjon. Skolen var tenkt som noe annet og mer enn et sted for læring. Det skulle også være en kulturimpuls i samtidens åndsliv (Steiner, 1989).

I min lesning har jeg vært på jakt etter alle stedene hvor Steiner omtalte kropp, kroppslige prosesser og bevegelse. Så har jeg sett etter mønstre i hvordan han omtalte dette og hvordan han satte det i forbindelse med undervisningspraksis, læring og danning.

Foredragsrekken har en viss struktur. De åtte første har en allmenndidaktisk form hvor barnets utvikling og hva det betyr for lærerens didaktiske valg, blir beskrevet grundig. Dette blir sammenholdt med en rekke utdanningshistoriske prosesser. Det han kalte "det greske oppdragelses-ideal» gikk blant annet igjen som en rød tråd (Steiner, 1986, s. 19). De fire neste er mer fagdidaktisk orientert, til dels med instruksjoner og eksempler på undervisningspraksis i ulike fag. I det siste foredraget vendte han tilbake til en mer overordnet betraktning over utdanningens plass i samtidens kulturutvikling og dermed Waldorfskolenes ambisiøse sosiale visjon. Jeg vil basere hovedvekten av mine refleksjoner på de åtte første foredragene.

\section{Ulike bilder av relasjonen mellom kropp og sinn}

Steiner åpnet foredragsrekken med å spenne opp et stort historisk bakgrunnsbilde som han så tok med seg når han i de senere foredragene gikk mer detaljert til verks om de ulike pedagogiske implikasjonene tenkningen hans har. Jeg skal først beskrive det store overgripende bildet, hans fremstilling av det greske oppdragelsesidealet.

\section{Drømmen om det greske oppdragelsesidealet}

Steiners store bakteppe i foredragene var et historisk tilbakeblikk på hvordan forholdet mellom det kroppslige og det sjelelige har kommet til uttrykk som ulike oppdragelsesidealer gjennom tidene. Han trakk særlig frem det klassiske greske oppdragelsesidealet gymnasten, hvor kropp og sjel var i fullkommen harmonisk balanse. «Det mennesket var gymnast som var i stand til å åpenbare verdens gudommelige skjønnhet i sitt eget skjønne legeme», sa han (Steiner, 1986, s. 19).

Harmoniseringen av kroppen var ifølge Steiner et viktig fundament for danningsprosessen i den greske kulturen. Han hevdet at grekerne ønsket «å utvikle det menneskelige legeme til en slik allsidig harmoni at det ble til en åpenbaring av gudommelig skjønnhet» (Steiner, 1986, s. 20). Steiner gikk i det andre foredraget 
detaljert til verks når han beskrev den kroppslige kultiveringen som foregikk i de greske gymnasium. Han beskrev vekslingen mellom trening av kraft og utholdenhet i brytekamper og annen idrett og musikalsk eleganse i ringdans og sang. Denne oppdragelsesformen var ifølge Steiner forankret i en forestilling om at det åndelige kunne komme til syne i den trente og grasiøse kroppen (Steiner, 1986, ss. 26-27). Dette har klare likhetstrekk med Platons lover for god oppdragelseskunst som ifølge Werner Jaeger vektla sang og ringdans som "a perfect example of the delight in good and beautiful activities which is to be developed in play at an early age, as a powerful stimulus to the development of the moral and aesthetic sense" (Jaeger, 1986, s. 228). Det gamle greske oppdragelsesidealet tegnet med andre ord opp en kobling mellom bevegelse, det estetiske og det moralske, og det er dette antikke oppdragelsesidealet Steiner knyttet an til.

Steiner fremstilte så hvordan oppdragelsesidealet gjennom romertiden og middelalderen gradvis løsrev det kroppslige fra det sjelelige og endte i et syn på dannelse som en ren indre sjelelig, åndelig og dermed intellektuell prosess adskilt fra kroppen. Dette ble av Steiner kalt doktorprinsippet. Hans egen samtids store oppgave, hevdet han, besto i å overvinne doktorprinsippet og gjeninnføre en oppdragelse av hele mennesket (Steiner, 1986, s. 22). Steiner mente at det var helt avgjørende å gjenoppdage de intime forbindelsene mellom kroppslige og mentale ressurser og hvilken betydning de hadde for oppdragelse og undervisning.

\section{Samspillet mellom fysiske og mentale prosesser}

Det overordnede bildet av et oppdragelsesideal som vil forbinde menneskets sjelelige/ åndelige side til kropp og bevegelse, sammenfattet Steiner i en enkel plante-metafor slik:

Liksom blomsten og frukten ligger skjult i plantens røtter i kimaktig tilstand - og vil kunne vokse og utvikle seg i lys og varme når bare røttene har fått den rette pleie slik er også den menneskelige sjel og ånd allerede tilstede i det gudommelig skapte legeme. Når man tar fatt i dette legemets «røtter», men vel og merke slik at man griper det gudommelige i dem, da utvikler også den iboende sjel og ånd seg like fritt av legemet som blomsten og frukten av plantens røtter (Steiner, 1986, s. 23-24).

Steiner presenterte med andre ord en metamorfose-prosess mellom det kroppslige og det mentale, hvor kroppslige ressurser, eller røttene, forvandles til mentale ressurser, blomsten og frukten. I foredragene brukte Steiner mye tid på å reflektere videre omkring samspillet mellom det mentale og det fysiske eller forbindelsen mellom det ytre og det indre mennesket. Han sa blant annet følgende om språket: «Barnets tale utvikler seg igjen av evnen og ferdigheten ved å kunne orientere seg i rommet», og videre: «Talens hele nyansering er gitt i bevegelsesorganismen. Livet er først gestus og geberde - som så forvandler seg på det indre plan til talens motoriske element [...] Det ytre forvandles og blir i det indre omsatt til sprogets bevegende kraft» (Steiner, 1986, s. 72), og språkets bevegende kraft danner i neste omgang utgangspunktet for 
tenkningens kvalitet. Steiner beskrev med andre ord indre liv som et resultat av kroppens bevegelser i rommet rundt seg. Det kan sammenfattes slik: Kroppslig bevegelighet blir språklig bevegelighet og ender som tankemessig bevegelighet.

Steiner beskrev samtidig det jeg vil kalle en negativ korrelasjon mellom kroppslige og mentale prosesser og hevdet at «legemet blir svakere, men sjelen sterkere» på veien fra barn til voksen (Steiner, 1986, s. 31). Kroppens vitalitet og vekstkraft må med andre ord holdes tilbake for at bevissthet og tenkning skal kunne oppstå. For å forstå dette ved hjelp av Steiners egen plantemetafor, kan det sammenlignes med det som skjer når en plante slutter å vokse og heller bruker all energi på å sette blomst og frukt. Steiner brukte her tannfellingen i 6-års-alderen som eksempel og hevdet at avslutningen av tennenes framvekst fra kjeven innebar slutten av en vekstprosess. Det innebar at visse mentale ressurser som hukommelse og indre forestillingsevne i større grad ble giort tilgjengelige (Steiner, 1986, s. 31).

Steiner presenterte med andre ord komplekse og flertydige forestillinger om sammenhengen kropp-bevegelse-mentale prosesser i Oppdragelse og tidens åndsliv. Hans hovedpoeng var at kroppen ved riktig pleie gir gode forutsetninger for et rikt og bevegelig mentalt liv, slik god næring til rota gir gode vekstvilkår for blomst og frukt. Jeg skal ikke gå nærmere inn på flere spesifikke forbindelser mellom disse to polene som er beskrevet i foredragene. Jeg skal heller forsøke å danne meg et overordnet bilde av hvilke ontologiske landskap Steiner beveget seg i når han beskrev disse tingene, og det viser at likhetstrekkene mellom han og andre samtidige tenkere bare er tilsynelatende.

\section{Et forsøk på å plassere Steiner som pedagogisk filosof}

Det er tilsynelatende klare likhetstrekk mellom Steiners tenkning om relasjonene mellom det kroppslige og det mentale og samtidens øvrige reformpedagogiske ideer. Det er blant annet verdt å merke seg at også Dewey løftet fram det greske oppdragelsesidealet som et forbilde: Han skrev at «a chief cause for the remarkable achievements of Greek education was that it was never misled by false notions into an attempted separation of mind and body» (Dewey, 1916, s. 166). Steiner så ut til å dele en slik monisme som utgangspunkt for pedagogisk virksomhet, men det er også klare ulikheter. Der Dewey var en utpreget naturalistisk orientert monist og beskrev menneskets opplevelse og erkjennelse som en del av en altomfattende natur (Dewey \& Fink, 1974, s. 31), var Steiner en spiritualistisk orientert monist som så på naturen som en del av en altomfattende åndelig dimensjon. I Oppdragelse og tidens åndsliv kommer dette for eksempel til uttrykk i det sjette foredraget, hvor han sa at: «det som på ett stadium i livet er av åndelig sjelelig natur, åpenbarer seg senere på det fysiske plan" (Steiner, 1986, s. 71). De hadde med andre ord ulik forståelse for hva som kommer først av essens og eksistens. Å sammenstille Steiner med annen sentral reformpedagogisk tenkning er med andre ord ikke problemfritt.

Det samme gjelder den tilsynelatende overensstemmelsen mellom forestillingen om «legemet som grunnlag for potensiell sjelelig og åndelig utfoldelse» (Steiner, 
1986, s. 24) og en fenomenologisk forestilling om kropp slik det ikke minst kommer til uttrykk hos Maurice Merleau-Ponty $(1979,1994)$ når han beskriver kroppen som utgangspunkt for selvopplevelse, språk og tenkning. Det kan se ut som det finnes mange sammenfallende forestillinger mellom Steiner og kroppsfenomenologien, men det er åpenbare forskjeller mellom disse to betraktningsmåtene. Det gjelder ikke bare med hensyn til hva som kommer først av essens og eksistens, men også fordi Steiner hadde en forestilling preget av metamorfose-tenkning. Det som først er en kroppslig kapasitet, vil på et senere livsavsnitt forvandles til en mental kapasitet. Han hevdet at ytre bevegelse ble forvandlet i det indre til tale og tenkning (Steiner, 1986, s. 72). Ifølge Merleau-Pontys kroppsfenomenologi er det derimot snakk om en umiddelbar og samtidig relasjon mellom kropp og bevissthet hvor det mentale oppstår i bevegelsen slik fotavtrykket i sanden oppstår idet foten settes ned. Det eksisterer, i et slikt perspektiv, ingen indre eller ytre verden som sådan (Zahavi, 2003).

Det er med andre ord ikke sammenfallende ontologiske ståsted mellom Steiner og andre reformpedagogiske og filosofiske ideer om kroppens betydning for bevissthet, språk og tenkning. Steiner var ingen naturalist eller eksistensialist i ordets rette forstand selv om han beskrev tette bånd mellom vår eksistens som kropp og vår eksistens som ånd. Naturen og dermed også vår kropp var for Steiner et sted for åndens tilsynekomst. Dewey ville sannsynligvis ha snudd dette på hodet. Det kan være at Steiners pedagogiske impuls på tross av disse ontologiske forskjellene allikevel kan bidra til å verdsette kroppens- og bevegelsens plass i skolen høyere.

\section{Kropp og bevegelse som en inngang til danning}

Steiners overordnede pedagogiske ide var som sagt å skape en motkultur mot det han kaller doktoridealet i skolen, og gjenopplive gymnasten. Doktoridealet som har preget skolen siden middelalderen, hadde ifølge Steiner spaltet mennesket i to uforenlige sfærer og medført at forståelsen av en sammenheng mellom mennesket som kropp og mennesket som sjel eller ånd var tapt. Å lære å se mennesket som en enhet innebar at pedagogisk praksis måtte forholde seg til mennesket som både tenkende, følende og kroppslig handlende i alle lærings- og danningsprosesser. Derfor fremstår steinerpedagogikken med rette som anti-dualistisk eller monistisk. Kroppen har ifølge Steiner en avgjørende plass $i$ alt elevene opplever i skolen, og skal ikke reduseres til mekanisk trening i gymsalene og for øvrig være mest mulig usynlig og i ro.

Den mest konkrete pedagogiske praksisen Steiner beskrev som et tiltak for å bøte på dette, er bevegelsesfaget som kalles eurytmi. For å beskrive intensjonen med eurytmifaget grep han nok en gang tilbake til gymnasten og den gamle greske kroppskunsten. Han pekte særlig på betydningen den greske kulturen la i kroppens kultivering gjennom kunstnerisk og musikalske uttrykk, med andre ord der kroppen og følelsene griper inn i hverandre og dermed gjør det musiske og dansende til en del av danningsprosessen. Steiner brukte uttrykket gudommelig gymnastikk om en slik 
aktivitet (Steiner, 1986, s. 33), og det samsvarer med det Platon i sin tid løftet frem når han i Jaegers gjengivelse sa at: "The educated man is a dancer» (Jaeger, 1986, s. 228). Sang og dans ville ifølge Steiner gjøre kroppen til et velstemt instrument hvor det sjelelige/åndelige kunne komme til uttrykk i verden.

Steiner presenterte eurytmi som et kunstfag som hadde som hensikt å forsterke forbindelsen mellom det følelsesmessige og det kroppslige i møte med språk og musikk. Han sa at: «Eurytmien kan [...] karakteriseres som beveget musikk. Det som sjelen føler, løser seg i dette tilfellet helt fra mennesket og blir til bevegelse i rommet» (Steiner, 1986, s. 161). Dette utsagnet peker på hvordan følelsene som i utgangspunktet kommer til syne i kroppslige gester, gjennom eurytmi, utvides ut over hva kroppen normalt kan gi uttrykk for. Gjennom dans fylles hele rommet av menneskets ulike følelsesnyanser.

Slik jeg tolker Steiners presentasjon av eurytmi, er forbindelsen mellom kropp og følelser et sentralt motiv. Fagets misjon er å kultivere og forsterke gestenes følelsesuttrykk, og en kropp som har det en kan kalle et harmonisert følelsesuttrykk, er ifølge Steiner utgangspunkt for et levende bevegelig språk som senere danner grunnlaget for en levende og bevegelig tenkning. Eurytmifaget gjør bevegelse i skolen til mer enn trening av spenst, styrke og smidighet i kroppsøvingsfaget. Det skal ikke trene kroppen i instrumentell forstand. Det påfallende er at det heller ikke er knyttet til læringsprosesser. Waldorfskole-forskeren Freda Easton beskriver eurytmien slik:

It provides an opportunity for the child to develop specific capacities such as spatial orientation, powers of concentration, and grace in movement, but most importantly it enables the child to experience a sense of inner balance and wholeness in community with others (Easton, 1997, s. 90).

Eurytmifaget skaper en balanse mellom den enkeltes kropp og rommet omkring og dermed også mellom det enkelte subjekt og fellesskapet det er en del av. Dette er etter min mening et interessant nytt uttrykk for en klassisk humanistisk forståelse av danning, eller bildung, slik den tok form i opplysningstiden (Westbury, 2000). Mange av bildung-tradisjonens grunnforestillinger ble ført i pennen av Wilhelm V. Humboldt (1767-1835). En klassisk forståelse av veien til danning måtte ifølge Humboldt innebære en livlig utveksling mellom barnet og verden. Resultatet skulle være at barnet i sin konstitusjon virkeliggjorde det allment menneskelige og det unike individspesifikke samtidig (Humboldt, 2000). I en monistisk forståelse må nødvendigvis en livlig utveksling bli betraktet som en prosess som starter i kroppen og dens bevegelse i verden, og det genuint menneskelige må også kunne komme til uttrykk i kroppens individuelle måte å bevege seg på.

Bortsett fra at Steiner tidlig i sin karriere var sterkt forbundet med to andre skikkelser fra Humboldts idemessige omgangskrets, Schiller og Goethe (Lindenberg, 1992), har det ikke vært vanlig å plassere ham i en slik klassisk pedagogisk bildung-tradisjon. I det siste foredraget reflekterte Steiner eksplisitt omkring denne humanistiske danningstradisjonen. Han pekte på at det latinske språket i sin tid var 
et synlig kjennetegn på det såkalte genuint menneskelige. Å være et dannet menneske innebar å beherske latin.

Steiner påpekte så det åpenbare. Denne danningsmarkøren hadde mistet en slik funksjon og fremsto i hans samtid som et innholdsløst, dødt skall. Steiner så på antroposofisk inspirert praksis som en mulig erstatning. Han sa det slik: «Ser vi på antroposofien ut fra et historisk perspektiv, er dens oppgave i vår tid å bli et internasjonalt redskap til gjensidig forståelse mellom menneskene, - et forståelsesmiddel som ligger et plan høyere enn språket» (Steiner, 1986, s. 172). Steiner hevdet med andre ord at en gjennom en skole inspirert av antroposofi kunne initiere et nytt element av det genuint menneskelige i danningsprosessen tilsvarende det latin hadde vært i skolen tidligere. Det er i en slik vid kontekst jeg forstår Steiners bestrebelse for å overvinne doktoridealet og skape en skole med gymnasten som forbilde.

\section{En skole for mer enn læring}

En slik måte å forstå kroppens og bevegelsens plass i skolen på peker på det jeg mener kanskje er det viktigste kjennetegnet ved Waldorfpedagogikk slik det ble formidlet i disse foredragene. Allikevel kan foredragene leses som en appell til alle som etablerer, styrer og underviser i skolen som sådan, og når jeg i det følgende skriver skole, er det derfor ikke begrenset til steinerskoler.

For Steiner handlet skole tilsynelatende ikke primært om læring, men læring ble for ham et middel for å oppnå danning, og ikke et mål i seg selv. Det er tydelig når han for eksempel i det ellevte foredraget omtalte hensikten med å undervise i flere fremmedspråk fra starten av skoleløpet. Han reflekterte over hvordan ulike språk appellerer til ulike sider av menneskets konstitusjon og fortsatte: «Som De vil forstå, er det ikke av nyttehensyn, men ut fra et rent didaktisk-pedagogisk-humant prinsipp at vi begynner så tidlig med flere sprog» (Steiner, 1986, s. 136). Det er fagenes bidrag til dannelsesprosesser som ble vektlagt.

Det finnes andre nærliggende eksempler på en tilsvarende utdanningsfilosofisk tenkning i vår tid. To av de tydeligste representantene for dette er Giert Biesta og Stefan Hopmann. Også de løfter frem skole som noe annet og mer enn et sted for læring. Biesta påpeker, ved å problematisere det han kaller learnification, at læringsfokuset står i fare for å tildekke andre viktige dimensjoner ved skolens virksomhet. Det avgjørende er ikke hvordan barn effektivt kan lære det ene eller andre i skolen, men snarere hvorfor det ene eller det andre skal læres - det Biesta kaller "the purpose of education» (Biesta, 2006, s. 24). Hopmann på sin side betoner «bruken av kunnskap som et transformativt verktøy for å utfolde elevenes individualiteter og sosiale evner, kort sagt: danning av eleven gjennom læring» (Hopmann, 2010, s. 29).

Det originale i Steiners refleksjoner omkring det samme er, slik jeg ser det, hans betoning av kropp og bevegelse som et utgangspunkt for å løse skolens danningsoppdrag. Også bevegelse kan bidra til å utfolde elevenes individualiteter og sosiale evner. Bevegelsesfaget eurytmi, eller gudommelig gymnastikk, er et eksempel på hvordan 
dette kommer til uttrykk. Steiner omtalte ikke bevegelsene i eurytmi som en støtte for lese- og skriveopplæring eller som nyttig for å nå andre spesifikke kompetanseeller læringsmål. Intensjonen med å bruke tid på bevegelse i skolen var å kunne skape et grunnlag for en musikalsk bevegelig kropp som var kultivert som et instrument for det Steiner kalte det sjelelige og det åndelige. Jeg velger å uttrykke det slik: Skolen skal fremme danning av mentale, sosiale og moralske ressurser som hviler i, eller springer ut av, kroppslige prosesser.

Eurytmi var for Steiner først og fremst en kunstform med egenverdi, og det kan derfor sees som et bidrag til dreiningen av skolens oppgaveforståelse bort fra en ensidig instrumentell nyttetenkning. Kropp og bevegelse, slik Steiner så det, skulle derfor ikke inneha noen form for instrumentell funksjon. Bevegelseskunst skal ikke legitimeres gjennom hva de bidrar med i en læringsprosess. De skal bare legitimeres gjennom å bidra til det Steiner kaller en oppdragelse av hele mennesket i skolen, og utviklingen av mennesket som «et moralsk vesen» (Steiner, 1986, s. 57).

\section{Avsluttende kommentarer}

Med denne artikkelen har jeg ønsket å gi en håndsrekning til Steinerskolenes utfordringer ved å legitimere og begrunne sin praksis i vår tid. Det innebærer også å finne adekvate anvendelser av Steiners mange pedagogiske ideer. En drøfting av hans refleksjoner omkring kroppens plass i skolen kan være et lite bidrag i så måte.

Med utgangspunkt i en gjenoppliving av ideene fra det gamle greske oppdragelsesidealet, gymnasten, forsøkte Steiner i Oppdragelsen og tidens åndsliv å vise hvordan det såkalte doktoridealet i samtidens skole kunne bekjempes. Doktoridealet er et resultat av spaltningen av mennesket $i$ en ren intellektuell, kognitiv del og en ren mekanisk kroppslig del. Resultatet er en skole som er ensidig intellektualistisk og dermed et lett bytte for en teknisk rasjonell målstyringslogikk og et strengt læringsfokus. Kroppens plass i skolen blir i en slik kontekst henvist til mekanisk vedlikehold i kroppsøvingstimene og skal ellers holdes i ro.

Steiners motsats til dette var en skole hvor kroppen skulle aktualiserer og gjøres relevant for alle sider ved skolens virksomhet, men ikke i instrumentell forstand. Kropp og bevegelse skulle ikke reduseres til et instrument for bedre og mer effektiv læring. Kroppens betydning i oppdragelsen, slik Steiner betonte det, var i kraft av hva bevegelse som kunstnerisk uttrykk innebar for danningsprosessene, for det emosjonelle og det kognitive, det estetiske og det sosiale, og til syvende og sist, det moralske i mennesket.

Steiner skilte seg fra annen reformpedagogisk tenkning og inntok en annen ontologisk posisjon omkring kropp og bevegelse enn Deweys naturalisme eller MerleauPontys kroppsfenomenologi. Det er dessuten mye omkring hans spirituelle inngang til pedagogikk som er krevende for en leser i vår tid å forholde seg til. Allikevel ga han etter min mening et fruktbart bidrag til hva skole kan være, mer enn bare læring og ensidig vekt på intellektuelt arbeid. Steiner tilførte den klassisk humanistiske 
danningstradisjonen en kroppslig og sanselig dimensjon, og hans store ambisjon var å innføre et nytt uttrykk for det genuint menneskelige tilsvarende det latin én gang var for dannede mennesker. Hans bidrag var det dansende mennesket. Dette var og er fortsatt en dristig ambisjon, men jeg tenker vårt utdanningspolitiske klima trenger mange ulike stemmer for en annen måte å tenke skole på, også de mest ambisiøse.

\section{Forfatteromtale}

Dag Øystein Nome (født 1965) arbeider som førsteemanuensis i pedagogikk ved Universitetet i Agder. Han underviser i barnehagelærerutdanningen og har lang erfaring fra skole og barnehage. De senere årene har han skrevet en rekke artikler og bokkapitler om lek, danning, barndom, barnehage og skole. Hans doktoravhandling fra 2017 omhandler barn-barn-relasjoner i lek i småbarnsavdelinger, og han ga nylig ut boka Hverdagshendelsenes pedagogikk.

\section{Referanser}

Biesta, G. J. J. (2006). Beyond learning: democratic education for a human future. Boulder, Colo: Paradigm.

Bø, I., \& Helle, L. (2008). Pedagogisk ordbok: praktisk oppslagsverk i pedagogikk, psykologi og sosiologi (2. utg.). Oslo: Universitetsforlaget.

Dewey, J. (1916). Democracy and education: an introduction to the philosophy of education. New York: Macmillan.

Dewey, J., \& Fink, H. (1974). Erfaring og opdragelse. Oslo, København: Dreyer Christian Ejlers’ Forlag.

Easton, F. (1997). Educating the whole child, "head, heart, and hands": Learning from the Waldorf experience. Theory into Practice, 36(2), 87-94.

Eisner, E. W. (1991). The enlightened eye: qualitative inquiry and the enhancement of educational practice. New York: Macmillan Publ. Co.

Fjelland, R. (2007). "Universet er ikke slik det synes å vcere”. Filosofi og naturvitenskap i historisk perspektiv. Oslo: Universitetsforlaget.

Hangaard Rasmussen, T. (1996). Kroppens filosof: Maurice Merleau-Ponty. Brøndby: Semi-forlaget.

Hopmann, S. (2010). Undervisningens avgrensning: Didaktikkens kjerne. I J. Midtsundstad \& I. Willbergh (Red.), Didaktikk - Nye teoretiske perspektiver på undervisningen. Oslo: Cappelen Akademsik.

Humboldt, W. v. (2000). Theory of bildung. I S. Hopmann, I. Westbury \& K. Riquarts (Red.), Teaching as a Reflective Practice: the German Didaktik Tradition. New York: Routledge.

Jaeger, W. (1986). Paideia: the ideals of Greek culture:Vol. 3: The conflict of cultural ideas in the age of Plato (2nd ed., Vol. 3). New York: Oxford University Press.

Levin, D. M. (1985). The body politic: Poilitical economy and the human body. Human Studies, 8(3), $235-278$.

Lindenberg, C. (1992). Rudolf Steiner. Oslo: Antropos Forlag.

Marstrander, E. G. (2015). Steinerpedagogikk og reformpedagogikk. En drøfting av Rudolf Steiners pedagogiske ideer $i$ forhold til reformpedagogiske tanker og ideer i hans samtid. (Mastergradsavhandling) Rudolf Steiner University College.

Mathisen, A. (2000a). Kropp og sanser i lys av Steinerpedagogikken. Arabesk, 2, 9-14.

Mathisen, A. (2000b). Lytte med hendene - skape med hjertet Eurytmi for barn og ungdom. Arabesk, 3, 14-20.

Merleau-Ponty, M. (1979). Consciousness and the Acquisition of Language. Evanston: Northwestern University Press.

Merleau-Ponty, M. (1994). Kroppens fenomenologi. Oslo: Pax forlag.

Myhre, R. (1971). Store pedagoger $i$ egne skrifter: 5: Europeisk reformpedagogikk i det 20. århundre (Vol. 5). Oslo: Fabritius.

Paull, J. (2011). Rudolf Steiner and the Oxford conference: the birth of Waldorf Education in Britain. European fournal of Educational Studies, 3(1), 53-66.

Sethne, A. (1930). Om friere arbeid i skolen. Norsk pedagogisk årbok, 108-117. 


\section{Dag Øystein Nome}

Stabel, A.-M. (2016). Hva skal vi med skole? Steinerskolens historie $i$ Norge 1926-2016. Oslo: Pax forlag.

Steiner, R. (1986). Oppdragelse og tidens åndsliv. Oslo: Antropos forlag.

Steiner, R. (1989). Sociala synspunkter på fostran och undervisning. Järna: Telleby bokförlag.

Steiner, R. (1994). Barnets oppdragelse fra åndsvitenskapens synspunkt. Oslo: Antropos.

Steinerskoleforbundet. (2007). En lcereplan for steinerskolene 2007. Oversikt-steinerpedagogisk idé og praksis. Oslo: Steinerskoleforbundet.

Wagemann, J. (2015). Shared Intentionality: Phenomenological Conception and Consequences in Terms of Waldorf Pedagogy. RoSE-Research on Steiner Education, 6(1).

Westbury, I. (2000). Teaching as a Reflective Practice: the German Didaktik Tradition. New York: Routledge.

Zahavi, D. (2003). Fanomenologi. Fredriksberg: Roskilde Universitetsforlag. 